\title{
Study on the Evaluation Method of Quality Index of Service Industry
}

\author{
Huali Cai ${ }^{1, a,{ }^{*}}$, Ning Zhang ${ }^{2, b}$ and Bisong Liu ${ }^{3, c}$ \\ ${ }^{1,2}$ Quality Management Branch, China National Institute of Standardization, Beijing. China \\ ach12081@126.com, ${ }^{b} 578826687 @ q q . c o m,{ }^{\circ} 583451349 @ q q . c o m$, \\ ${ }^{*}$ Corresponding author
}

Keywords: Service Industry Quality; Indicator System; Evaluation Method; Index

\begin{abstract}
Despite the sound growth of China's service industry, the quality level of the industry in the country remains to be improved. In the existing documents, there is a lack of research on the integrated quantitative evaluation of service industry quality. This paper first introduces quality concepts and types, then studies the factors affecting quality and develops the evaluation indicator system for service industry quality. Exponential functions are introduced for the purpose of 0-1 processing of indicators. The weighted sum method is used to calculate annual service industry quality indicators. The result of calculation proves to satisfy practical conditions through empirical research.
\end{abstract}

\section{Introduction}

China's service industry has maintained a momentum of vigorous growth in the recent years. In 2013 , the added value of service industry contributed to $46.1 \%$ for GDP growth, making the industry surpass the secondary industry and become a new engine for China's economic growth. The industry had a share of 50.5\% in 2015 and $51.6 \%$ in 2016, evidencing the further optimization of the economic structure of the country. However, the rapid growth of service industry contrasts sharply with the lack of standards, poor regulation and low satisfaction in terms of its quality. The overall quality status of the service industry is quite worrying. The quantitative measurement of service industry quality can enable the direct discovery of the real quality and provide a strong policy support for the formulation of service industry policies.

Among the existing research documents on the quantitative measurement of service industry quality, Yan ZHANG mainly studies the measurement of customer satisfaction and Clay $\mathrm{M}$ the measurement of customer complaints as a single indicator. Among the existing documents, there is a lack of study on the integrated measurement of multiple service quality indicators. Starting from quality concepts, this paper divides service quality into two aspects, then designates indicators to each aspect and develops a mathematical model for calculation.

\section{Definitions of Quality Concepts}

1. Quality: How a group of inherent characteristics of the object satisfy requirements. In GB/T 19000-2016, the quality evaluation index system is divided into two types by reference to relevant research documents and some domestic practice: development capacity and quality level. Normally, object and subject attributes reflect the indicators of quality capacity and quality level respectively.

2. Development capacity: It's the foresight indicator of quality, which is used to indicate the trend of quality development.

3. Quality level: It's the indicator of quality status, used to show whether the quality is high or low and whether the development is leading or backward; for manufacturing industry, the capacity of R\&D and technical renovation is included.

4. Attributes of quality objects: Such attributes can be accurately measured and evaluated as they are normally reflected in the production standards and regulation requirements of service. 
5. Attributes of quality subjects: Such attributes are formed based on the subjective perception and expectation of customers and are reflected by customers' satisfaction towards services through experience.

\section{Factors Affecting Service Quality}

The factors affecting service quality are discovered as follows according to quality concepts:

1) Personnel: professional ethics, personal quality, service skills, service attitudes, service efficiency.

2) Machine: facilities, such as ATM for banks.

3) Material: Sold products, information relating to service process.

4) Method: standards, specifications and policies, etc.

5) Environment: safe, beautiful, convenient, comfortable, etc.

\section{Evaluation Indicator System}

The indicator system falls into two types according to the attributes of quality subjects and objects as well as factors affecting quality (including personnel, machine, material, method, and environment). Object attributes include:

(1) Number of new service industry standards, reflecting the "method" in quality factors;

(2) Number of service industry policies issued by government authorities, reflecting the "method" in quality factors;

(3) Total labor productivity of service industry (dimensionless), reflecting the "personnel" in quality factors;

(4) Number of management system certifications in service industry, reflecting all the five quality factors above;

(5) Number of service certifications, reflecting all the five quality factors above.

(6) Subject attributes include:

(7) Added value of service industry (unit: RMB Ten thousand), reflecting all the five quality factors above;

(8) Customers' satisfaction towards service industry (unit: point, total score: 100), reflecting all the five quality factors above;

(9) Number of complaints in service industry, reflecting all the five quality factors above.

\section{Calculating Method}

Step 1: Find out distribution functions according to the characteristics of individual indicators;

Step 2: Find out the 0-1 processing method on the eight indicators above;

For positive indicators, calculate the single-item evaluation result according to Eq. 1:

$f(x)=1-\mathrm{e}^{-\beta x}$

For negative indicators, calculate the single-item evaluation result according to Eq. 2:

$f(x)=\mathrm{e}^{-\beta x}$

Step 3: Calculate the value of $\beta$ by setting optimum and reference values;

Step 4: Handle all indicators through 0-1 processing;

Step 5: Calculate the annual service industry quality index SQI according to Eq.3:

$\mathrm{SQI}=\left(1 / \mathrm{n} * \sum_{\mathrm{i}=1}^{\mathrm{n}} \mathrm{ai} * 0.6+1 / \mathrm{m}^{*} \sum_{\mathrm{i}=1}^{\mathrm{m}} \mathrm{bi}^{*} 0.4\right) * 50+50$ 
Where,

$\mathrm{n}$-means indicator value of object;

$\mathrm{m}$-means indicator value of subject;

ai -means result of object indicator processing;

bi -means result of subject indicator processing.

\section{Application}

Due to the long duration in obtaining data, the simulation method is adopted on the indicators (1), (2), (4) and (5) to simulate the indicator data for the years 2013 to 2015.

Table 1 Index data of years 2013 to 2015

\begin{tabular}{|c|c|c|c|c|}
\hline $\begin{array}{l}\text { Indicator } \\
\text { No. }\end{array}$ & Indicator name & 2015 & 2014 & 2013 \\
\hline (1) & $\begin{array}{l}\text { Number of newly-issued national } \\
\text { service industry standards }\end{array}$ & 400 & 200 & 100 \\
\hline (2) & $\begin{array}{l}\text { Number of service industry } \\
\text { policies issued by government } \\
\text { authorities }\end{array}$ & 50 & 45 & 41 \\
\hline (3) & Total labor productivity & 10.54 & 9.82 & 9.38 \\
\hline (4) & $\begin{array}{l}\text { Number of management system } \\
\text { certifications }\end{array}$ & 10,000 & 9,000 & 8,500 \\
\hline (5) & Number of service certifications & 700 & 640 & 630 \\
\hline (6) & Added value of service industry & 346,150 & $308,058.6$ & $277,959.3$ \\
\hline (7) & Customer satisfaction & 75.25 & 75.1 & 74.49 \\
\hline (8) & $\begin{array}{l}\text { Number of customer complaints } \\
\text { in service industry }\end{array}$ & 2.4 & 2.08 & 2.02 \\
\hline
\end{tabular}

Table 2 Index data after $0-1$ processing

\begin{tabular}{|c|c|c|c|c|}
\hline $\begin{array}{l}\text { Index } \\
\text { No. }\end{array}$ & Index name & 2015 & 2014 & 2013 \\
\hline (1) & $\begin{array}{l}\text { Number of newly-issued national } \\
\text { service industry standards }\end{array}$ & 0.996094 & 0.9375 & 0.75 \\
\hline (2) & $\begin{array}{l}\text { Number of service industry } \\
\text { policies issued by government } \\
\text { authorities }\end{array}$ & 0.815592 & 0.781625 & 0.75 \\
\hline (3) & Total labor productivity & 0.789387 & 0.76574 & 0.75 \\
\hline (4) & $\begin{array}{l}\text { Number of management system } \\
\text { certifications }\end{array}$ & 0.804253 & 0.769578 & 0.75 \\
\hline (5) & Number of service certifications & 0.785689 & 0.755441 & 0.75 \\
\hline (6) & Added value of service industry & 0.822074 & 0.784848 & 0.75 \\
\hline (7) & Customer satisfaction & 0.7525 & 0.751 & 0.7449 \\
\hline (8) & $\begin{array}{l}\text { Number of customer complaints } \\
\text { in service industry }\end{array}$ & 0.71049 & 0.743619 & 0.75 \\
\hline
\end{tabular}


The quality indexes of service industry from 2013 to 2015 are $79.92,82.27$ and 83.51 respectively, which conform to practical conditions.

\section{Acknowledgement}

This work was funded by the Dean fund project of China National Institute of Standardization under grant No. 642015Y-4009, the National Key Technology R\&D Program of the Ministry of Science and Technology under grant No. 2013BAK04B02 and 2013BAK04B04.

\section{References}

[1] Yan ZHANG. Theoretical Analysis and Cultivation Countermeasure of Customer Loyalty in Hotel Enterprise[J] . Canadian Social Science . 2009 (4)

[2] Clay M. A Service Perspective on the Drivers of Complaint Intentions. Voorhees,Michael K. Brady. Journal of Service Research . 2005 